\title{
Waiting for the Sound of Postmodern Art (A Historical Study)
}

\author{
Iswahyudi $^{1}$ \\ ${ }^{1}$ Department of Fine Arts Education, Yogyakarta State University, Depok 55281, Yogyakarta, Indonesia
}

\begin{abstract}
The shift from modernism to postmodernism remains an interesting discussion. One of the approaches in this notion is to view postmodern in a constructivist or revisionary model. In this case, postmodernism serves as a follow-up of modernism. From a historical perspective, the total historical model may no longer be relevant due to its dependence on the diachronic-synchronic discourse, that continuously extends in time. On the other hand, the discussion on postmodernism always highlights the partial aspects that focus more on local narration and are ultimately opposed to grand narration. Still in the context of postmodernism from the historical perspective, art is seen as a Ferris wheel. As various segments of art are still discussed as social realities, there needs to be a reconstruction of postmodern power of creation that constantly represents an intertextual relationship between one type of art and another. In terms of the postmodern aspects in art, the development of the discourse also turns to feminism and multiculturalism. Whether art has any analogue implications with the two perspectives, perhaps as a source of inspiration, will be addressed in this discussion.
\end{abstract}

Keywords: art, modernism, style, postmodernism

\section{INTRODUCTION}

The change from modern to post-modern is a natural thing, if the mechanism of history must be that way. Postmodern emerged with a loud voice protesting the results of the thought of an established and legitimated product of modernity. The long debate about the transition from modern to post-modern is full of philosophical problems, especially regarding to epistemology. Too many interpretations and various interpretations of post-modern make it become lively and frenzied so that it produces an empty intellectual like a jungle inhabited by various kinds of animals.

Different from this opinion, post-modern development models can be roughly divided into deconstructive and constructive or revisionary [1]. The first theory was originally pioneered by philosophers that is Gianni Vattimo and Derrida. Then, followed by thinkers of language semiotics that is Ferdinand de Saussure and visual semiotics Charles Sander Pierce. Constructive theory in which its mission of dismantling the picture of the modern world actually still maintains various aspects of modernity that are considered important in order to uphold creating something that is considered new. This model tends to be dominated by hermeneutic thinkers, as are Gadamer, Paul Ricouer and David Griffin. Different from this model, this paper can lead the reader to discover how far the journey of post-modern art goes.

\section{FROM MODERNISM TO POSTMODERNISM}

Modern arts, especially in the West, have been discussed since 20 th century. The themes shown generally are around protests against works of art that are considered to have low values due to the influence of the bourgeoisie in art. There was also concern that cultural interventions were too vulgar. Because of the consideration of opposing positions that deviate from the dominant traditions found in their various cultural backgrounds, the members of the pioneering arts group tried to create a work of art that was believed to be pure art in its true sense. Although in some ways it was anticipated by certain phenomena contained in the movement in the Romantic period at the beginning of the 19th century and supported by the opinion that art is for art itself, but awareness of modernism can be concerned as emergency. Charles Baudelaire in 1821-1867 was a stretcher of impressionism and as a poet, he was very good at making unexpected images. He made personifications of abstract things or visual representations that are as astounding as those in his works. [2] In fact, one of the most prominent characteristics of modernism that distinguishes it from previous cultures such as the flow of romanticism, realism or naturalism is the systematic and awesome categorization. The energy that emerges in each section recognized as its strengths are the schools: post impressionism, symbolism, cubism, vorticism, imaginism, akmeism, and neo-plasticism. 
The term modernism was first used in 1890 by a Nicaraguan writer Ruben Dario in 1867-1890 to distinguish between Latin American literature and Spanish literature. Until the $1920 \mathrm{~s}$, modern artists managed to maintain the method of inspiring and integrating various art groups as a cultural force. Among these artists are: James Joyce in 1882-1941, Marcel Proust in 1871-1922, and Andre Breton in 1896-1966. James Joyce asserted that using parody is a past recycling strategy that can help find conventions of representation [3]. Marcel Proust is a linguist with the work "À La Recherche du temps perdu." This whole romance returns to the past through awareness and reflection [4]. Andre Breton in 1896-1966 proposed a theory, that super reality must be an idea even though there must be chaos. One of his literary works, umbrellas and machines falling in love can change fake absolutes into something different. [5]

The historical event concerning the success of modernism in the field of art which was not easily obtained in the middle of the century had a complex relationship between art modernism and the course of European history. The adherents of modernism often choose the daily lives of Europeans as the subject of the success of the label of modernization so that the massive use of experimental methods of natural science gives satisfactory results. The elitism that they use implies the existence of: "high level art" and "low level art ". The occurrence of cultural and political crises cannot be avoided, both on the right and left. Some of them are like poets T.S. Eliot, used parody in modern art is to emphasize convention and history. However, post-modern irony is the irony that rejects the resolution of modernism at the conclusion or at least reasoning. Both cannot be released from complications [6].

Before modernism was even half a century old, new hopes for art began to emerge. The modernists prioritize the element of purification projects in their works. Hence, modernism will foster the development of pure fine arts within the reach of human endeavours such as; ethics, politics, religion and economics. Likewise, there is a clue about the echo of the motto "art for art" which causes functional art to be retained. What Roger Shattuck called "old-fashioned modernist art" is to put back the transition process in the arts with one of the classical approaches. Imagic poets such as Pound tried to erase abstract elements in his works. He tried to eliminate conceptual language and found ways to show the various soul experiences that were introduced in the art world by Bergson and a critic, T.E Hulme.

\section{MODERNIST WORSHIP ON THE HIGH AESTHETICS}

High aesthetics is emphasizing both the quality and technical aspects. Since the birth of modern art or modernism in the art, it seems that high culture in its manifestation represents the real achievement of culture. In this case, one of them is painting. As an alibi, because it is made by canvas, it is possible for the painted paint to keep images more strongly compared to other materials. Another development of this high art is also attached to aspects of prices that can be expensive and get a special portion of one of the fine arts [7]. High aesthetics cannot be understood if they do not contrast them with low aesthetics. Enrichment of high culture is already done as in the course of European history that shapes identity, so that it is representative of its high aesthetics. Conversely in low aesthetics, it is considered as a procedure of the need for mass culture or subsistence objects, so the results are considered to have no standards of cultural outcomes that are promoting, improving and enlightening life [8].

In general, modernists see the form of art as purely a free form from the art form itself. For example, in some modernist dramas such as Luigi Pirandello's 1921 "Six Character in Search of an Author", theatrical imaginary realms and audience involvement in the illusions appear to be evident in the drama. These are things that appear in the era of modernism which eventually created the mainstream of art that is contrary to traditional art, as did Lawrence Sterne, the author of anti-novel "Tristram Shandy" in the 18th century. [9]

By pursuing this logical aesthetic purification, the retrospective (past), as written at that time often emphasizes the excessive goals. Modern trends in the field of art are the same as those in architecture, which is univalent. In contrast to painting, modernism is often interpreted in terms of "abstraction of pure advanced forms", colours and textures that mimic things that are anecdotal and emotional outside the canvas. Thus, the flat lattice turned into a new flow of anti-perspectivism which is symbolic, which is not in line with the attention of the illusionists to traditional painting. Modernist sculpture can survive in abstraction, not only from representative topics (especially about humans), but also in terms of cultural significance where buildings such as churches, palaces, or public parks are usually placed, arts inspirational sources of modernist. Regarding the types of music of the modernists, especially those related to the Second Viennese School or the music school led by Arnold Schoenberg in 1874-1951, it is known to explore musical forms after the crisis of tone. Therefore, to ignore the interests of musicians, it is to pay attention to their listeners or arouse their feelings. Even the most referential phenomena or visual phenomena, that is photography can develop into a kind of high-level art and can survive as one of the symbols of beauty and pure images born from the talented hands of an artist through mechanical processes in a camera. The pattern relationship between narrative and photographic sequences is destabilized in the work of Duane Michals and Victor Burgin [10]. 


\section{MODERNISM CRISIS, HIGH LEVEL}

Modernism is still believed for three centuries in the interest of the emergence of a new cultural atmosphere. In line with the end of the 20th century, there is no history of other civilizations that can replace the era of modernism. In fact, the only possible possibility is a temporary atmosphere or cultural flow. Due to many opinions about the name of this school show that there is no stability. From a post-modern point of view, suggesting reading in chronological order in time as a cultural movement, so that it can replace the flow of modernism which can no longer be called as something new. As is well known, postmodernism makes a difference with other post-posts such as post-historical, post-structuralist, post-Marxism, and post-industrial social.

Movements such as Dadaism, futurism and sur-realism can now be considered capable of removing the line between art and life, like the techniques owned by German militant artist Bertolt Brecht. In his theatre work, Verfremdungseffekt, Brecht is developing a theory of distance Marxist theatre that directs the theatre to no longer be "dramatic", but "epic". Theatre performance is not intended to involve the emotions of the audience in shocking moments, but shows how human life moves in line with changes in social and economic aspects of a particular society [11]

\section{POSTMODERN AND POLLUTED ADVANTAGES}

Post-modernism is then interpreted as a turning point of purification and differentiation in high modernism. Adherents of modernism often dispute the issue of style to create beautiful works. However, unlike Joyce, postmodernism rejects the goal of aesthetic sublimation, because the results will be random. Robert Venturi stated that in the 1970s, there was a rapid development of design. The design world also experienced a massive shift, especially related to the principles of efficiency and fuel use that led to simple designs such as practical, energy saving and beautiful Soft lines [12]. Related to installation art, the most important and quite significant is that the process of creating is a unitary unit that also determines the size and value of his artwork. Event elements such as Happening Art/Performance Art or precisely the process of occurrence of an event has been considered as a representation. The contact between the object and the audience feels so heavy and this, the process of occurrence is the result of our own work. Thus, regarding to the form, installation is still an art that is developing, starting from the ideas and concepts of expression to the level of reaction such as the use of multimedia technology effects, movements (kinetic), lights (laser), music, dance, and video in effect an association that now continues to blow the art life that exists today. For instance, Joseph Buys with his monumental works such as wrapping buildings, bridges, fencing mountains and so forth.
There is also concept art or conceptualism. Before the 1970s art was considered valid only if it had physical appearance such as paintings, poetry books, songs, sculptures and so on. However, concept art validates notes, concepts and ideas as a work of art. This art states that even ideas can be considered beautiful and interesting. It is said that the emergence of this school was due to a crisis in painting and the impasse of a formalist and minimalist aesthetic. Movements like the Bauhaus, Sur-realism and Futurism are directed at the reflection of artistic values. The spirit of the constructivists was replaced by a spirit of deconstruction that shifted the difference with what Jacques Derrida called "difference" [13]. Although they tried to subvert their opponents, in fact, it never worked. According to Charles Jencks, a post-modern architectural figure, the end of that hope was on July 15, 1972 [14]. At that time, the Pruit-Igoe housing project in St. Louis, Missouri was blown up, so the aim was to provide mass housing through what French architect modernism Le Corbusier said was "an engine for life" and had to end [15].

What was known as "Pop Art" or popular art in the 1960s was an art development that was influenced by the symptoms of popular culture that occurred in the community. Pop Art was started in London in the mid1950 s by an independent group of artists and intellectuals. Then, this thing developed into the United States. The birth of "Pop Art" is more or less influenced by the hustle and bustle of the state of development of mass communication media and the trade industry between developed countries, especially in Europe and America. In America, "Pop Art" is a reaction to abstract or non-object art. Richard Hamilton in 1956 made a work entitled "Just What Is It That Makes Today's Home So Different, So Appealing?". When the art of "Pop Art" was influential in the United States, Andi Warhol was successful and achieved a reputation even without turning a blind eye that the influence of industry brought the art down to the ethics of art production [16]. Modernism is believed to develop in popular culture that surrounds it as newspapers, books, catalogues, advertisements, and also music. Unlike the post-modernists, they prefer to question the hierarchy. Possibly, they argued in discussions created, as in postmodernism novels such as Umberto Eco's The Name of the Rose. According to Adele J. Haft et al., this book is a complex masterpiece that is enigmatic, multi-layered and offers a variety of open interpretations [17]. 


\section{ALTERNATIVE LIBIDO BETWEEN FEMINISM AND MULTICULTURALISM}

In modernist art, some critics recognize that aesthetics open up a variety of possibilities for discourse to become extinct. After the era of modernism, there was a gender issue which later became more developed after this era of modernism. At the end of the 19th century, society was described as a woman; irrational, unable to control themselves, and do not have high cultural values. This is illustrated by literary critics such as Hippolyte Taine in 1828-1893 (factors such as absolute climate of accepted truth. Taine found that the nature of human nature is determined by the universal laws of determinism that govern biological and physiological especially the nature of heredity, psychological conditions influenced by physiology). Not surprisingly, the culture of society also experiences the same thing, so it is often compared with the spiritual values of the modernist elite. Related to this, many modernists remain discriminatory against women who are considered culturally inferior as is the culture of society which is considered to be backward or regressive and low-level. While men are considered as producers of culture, able to do various kinds of reorganizing, and women are considered as consumers (users) of culture as sentimental fiction, according to their inferior status.

Post-modernism that emerged when the feminists criticized about post-modernism is that it cannot be ignored, has lost its sense, not only for the narrative of its master artists, but also for the narratives of leading artists of the sex masculine. Post-modernism also requires the incorporation of work as post-colonial artists did, some of whom lived in what was once European power, while others settled and assimilated into the original nation. The spirit of magical realism possessed by Latin American novelists such as Gabriel Garcia Marquez who is famous for his work Chronicle of a Death Foretold [18] as there is an affirmation that is not only for the metaphysical joy of the novel but also a historical and political act.

Because post-modernism consciously seeks to remove the gap between aesthetics and non-aesthetics, some thoughts such as thinking about gender (gender differences), ethnicity, and multiculturalism (many cultures) enter the world of discussions around that problem. Attempts were made to link it to a broader process of modernization. As the case related to modernism, the effects of new technologies such as airplanes, cinema, radio, and now computers, glass lenses, and video are believed to be the process of revolutionizing cultural imagery such as cyborgs, cyberspace and cyberpunk, all becoming words that easily captured or accepted that reflects changes in artistic products.
However, although post-modernism as a cultural condition had been created, its origins were explained in a wider range of social fields, in economic and technological strength, after all the urgent nature possessed by this school can be understood. Of course, it is still too early to write a balance in post-modernism itself, and other results can still emerge if this flow continues to maintain the use of multiple narratives. The position of the subject matter becomes diverse if it does not use perspective or overall perspective in its golden age.

\section{CONCLUSION}

The post-modern term is always associated with major changes in history, including in term of art. The strongest issue occurred in the 1930s, but experienced dimming in the 1970s, and peaked again in the discourse in the early 21 st century. Since then, post-modern art has again been used to refer to a style. Post-modern art, in this view, is still connected continuously with the previous modern art which placed an autonomous in accordance with the internal logic of each creator. In the historical course, it is found that every work of art including art media that is interconnected with the creator is accommodated in; high esteem worship, the crisis of modernism in art, experiencing a dilemma between superior and humiliated art, and being trapped in the realm of democratization must choose between feminism and multiculturalism. 


\section{REFERENCES}

[1] Sugiharto, I. Bambang. Postmodernisme: Tantangan bagi Filsafat [Postmodernism: A Challenge for Philosophy]. Kanisius, 1996. p. 16.

[2] Husen, Ida Sundari. Mengenal Pengarangpengarang Prancis dari Abad ke Abad [Get to know the French authors from Ages to Ages]. Jakarta: Grasindo, 2001. pp. 130-134.

[3] Hutcheon, Linda. Politik Postmodernisme [Postmodernism Politics]. Yogyakarta: Jendela, 2002. p. 157.

[4] Husen, Ida Sundari. Mengenal Pengarangpengarang Prancis dari Abad ke Abad [Get to know the French authors from Ages to Ages]. Jakarta: Grasindo, 2001. p. 167.

[5] Susanto, Mikke. Membongkar Seni Rupa [Exposing Fine Arts]. Buku Baik, 2003. p. 11.

[6] Hutcheon, Linda. Politik Postmodernisme [Postmodernism Politics]. Yogyakarta: Jendela, 2002. p. 158.

[7] Raymond, Williams. Keywords: A Vocabulary of Culture and Society. London: Fontana Press, 1985. pp. 90-92.

[8] Gans, Herbert. Popular Culture and High Culture: An Analysis and Evaluation of Taste. Basic books, 1975.

[9] Hutcheon, Linda. Politik Postmodernisme [Postmodernism Politics]. Yogyakarta: Jendela, 2002. p. 296.

[10] Hutcheon, Linda. Politik Postmodernisme [Postmodernism Politics]. Yogyakarta: Jendela, 2002. p. 67.

[11] Camus, Albert. Seni, Politik, dan Pemberontakan [Art, Politics and Rebellion]. Yogyakarta: Yayasan Bentang Budaya, 1998. p. xxvi.

[12] Susanto, Mikke. Membongkar Seni Rupa [Exposing Fine Arts]. Buku Baik, 2003. p. 83.

[13] Derrida, Jacques. Margins of Philosophy. University of Chicago Press, 1982. p. 2.

[14] Jencks, Charles, et al. The Language of Postmodern Architecture, $4^{\text {th }}$ ed. London: Academy Editions, 1984.

[15] Grenz, Stanley J. Pengantar untuk Memahami Postmodernisme [Introduction to Understanding Postmodernism]. Yogyakarta: Andi, 2001. p. 25.
[16] Marcel, Danesi. Pesan, Tanda dan Makna: Buku Teks Dasar Mengenai Semiotika dan Teori Komunikasi [Messages, Signs and Meanings: Basic Textbooks About Semiotics and Communication Theory]. Yogyakarta: Jalasutra, 2012. p. 252.

[17] Haft, Adele J., Jane G. White, and Robert J. White. The Key to the Name of the Rose. Yogyakarta: Jalasutra, 1999. p. 12.

[18] Márquez, Gabriel García. Chronicle of a Death Foretold. Ballantine, 1982. 